\section{Composted Dairy Manure and Alfalfa Hay Mulch Affect Soil Ecology and Early Production of 'Braeburn' Apple on M.9 Rootstock}

\author{
Tom Forge², Gerry Neilsen, Denise Neilsen, Eugene Hogue, \\ and Dana Faubion ${ }^{1}$ \\ Pacific Agri-Food Research Centre, Agriculture and Agri-Food Canada, \\ 4200 Highway 97, Summerland, British Columbia, V0H 1Z0, Canada
}

Additional index words. replant disease, root lesion nematode, Pratylenchus penetrans, fruit tree nutrition, soil food web, soil health

\begin{abstract}
A variety of organic mulches and amendments have been observed to improve soil quality and productivity of apple orchards. Alfalfa hay and composted dairy manure solids (CDS) are readily available in the apple-growing region of the Pacific Northwest and British Columbia and could be used to improve orchard performance. The objective of this research was to determine the influences of CDS amendment and alfalfa hay mulch on populations of soil microfauna, soil chemical properties, and early growth; nutrient uptake; and yield of apple planted into a fumigated coarse-textured soil in central Washington State. Alfalfa mulch significantly improved tree vigor and fruit yield with minimal adverse effects on fruit quality, whereas the CDS amendment had minor effects on vigor and yield. Both alfalfa mulch and CDS amendment increased availability and uptake into leaves and fruit of most key nutrients but plant nutrient concentrations were not deficient in control plots, suggesting that increased nutrient availability was probably not the primary reason for the increased vigor attributed to alfalfa mulch at this site. The alfalfa mulch resulted in elevated populations of microbivorous nematodes and protozoa that persisted through later years of the experiment, indicating greater overall microbial activity, mineralization of nutrients, and possible direct stimulation of root growth under mulch; the CDS amendment did not consistently enhance populations of microbivorous nematodes. The alfalfa mulch, but not CDS amendment, suppressed the buildup of populations of root-lesion nematodes, which are important components of the replant disease complex that was suppressing tree growth at the site despite the preplant fumigation. Accordingly, we speculate that the reduced impacts of root-lesion nematodes contributed to the improved vigor and fruit yield of trees grown with alfalfa hay mulch.
\end{abstract}

The productivity of apple orchards can be improved by the application of organic amendments and mulches to root zone soil (e.g., Hogue and Neilsen, 1987; Neilsen et al., 2003a, 2007). Fine-textured and relatively nutrient-rich organic materials such as composted manures are usually applied as soil amendments with the primary intention of improving soil organic matter, nutrient status, and biological activity. Coarser materials such as wood processing wastes (wood chips, bark chips, sawdust), paper wastes, or hay are

Received for publication 7 Jan. 2013. Accepted for publication 8 Mar. 2013.

This project was funded by the Washington Tree Fruit Research Commission and Agriculture and Agri-Food Canada's Matching Investment Initiative. We thank cooperating grower Dave Allan, Allan Brothers Fruit for field plot maintenance, Linda Herbert for technical assistance, and Mark Mazzola for performing a replant test on soil from the plot area.

${ }^{1}$ Previously Washington State University Extension, 128 N. 2nd Street, Room 133, Yakima, WA 98901-2631.

${ }^{2}$ To whom reprint requests should be addressed; e-mail tom.forge@agr.gc.ca. parasitic nematodes in apple (Forge et al., 2003, 2008; Stirling et al., 1995) and raspberry (Forge and Kempler, 2009) production systems, which have similar nematode pests.

In the Columbia basin region of the Pacific Northwest and the adjacent interior of British Columbia, alfalfa hay is readily available and is therefore a prime candidate low-cost mulch material for apple orchards in the region. Alfalfa can also potentially be grown between rows of apple and then mowed and raked or blown onto the tree row in a "mow and blow" mulch system (Granatstein and Sanchez, 2009). Alfalfa hay has considerably greater concentrations of nitrogen $(\mathrm{N})$, phosphorus $(\mathrm{P})$, potassium $(\mathrm{K})$, and other nutrients than most other organic mulch materials, and its potential influences on apple tree nutrition may be significant. Earlier research in British Columbia indicated that alfalfa hay mulch can improve yield and fruit size of 'Spartan' apple (Neilsen et al., 2003a). As well, it improved uptake of $\mathrm{N}, \mathrm{P}$, and K (Neilsen et al., 2003a), generally improving soil fertility (Neilsen et al., 2003b) and soil biology, including apparent suppression of root-lesion nematode (Pratylenchus penetrans) populations (Forge et al., 2003). Many large dairy farms are located in the Columbia basin, and composted dairy manure could also be a valuable organic nutrient amendment for orchards in the region, but its compatibility with apple production has not been studied to date.

Orchards in the region are often fumigated before replanting to reduce impacts of the replant disease complex. Soilborne plant pathogens that have been implicated in the poor growth of juvenile trees planted into former orchard sites include several genera of fungi, particularly Rhizoctonia, Cylindrocarpon, and Pythium, as well as the root-lesion nematode, Pratylenchus penetrans (Mazzola and Manici, 2012). Previous studies of the influences of organic amendments and mulches on orchard nematode populations were conducted on established orchards (Forge et al., 2003, 2008). Because fumigation creates a biological vacuum, the application of organic amendments and mulches to recently fumigated soil could have particularly strong influences on the development of soil biological communities in the root zone of young apple trees.

Responses of the apple production system to any given organic amendment or mulch are likely to vary according to soil type, presence of the replant disease complex, fumigation and other cultural practices, and plant genotype. Additional research to expand current understanding of the use of alfalfa hay and composted dairy manure solids as mulches and amendments for apple production is warranted. The objective of this research was to determine the influences of composted dairy manure solids (amendment) and alfalfa hay (mulch) on populations of soil nematodes and protozoa, soil chemical properties, and early growth; nutrient uptake; and yield of apple planted into a fumigated coarse-textured soil in central Washington State.

\section{Materials and Methods}

Experimental plot setup. 'Braeburn' apple [Malus sylvestris (L.) Mill var. domestica (Borkh.) Mansf.] on M.9 root stock was planted Mar. 2000 at $1.2 \mathrm{~m}$ (within row) $\times$ 2.6-m (between row) spacing (3205 trees/ha) on a coarse-textured soil in a commercial orchard in Naches, WA, and subsequently trained to a post and wire system. The soil was a Cleman very fine sandy loam (coarse-loamy, mixed, 
superactive, mesic Torrifluventic Haploxeroll). Soil fertility analyses before planting indicated optimum soil $\mathrm{pH}, \mathrm{K}$, calcium (Ca), magnesium (Mg), P, low salinity values, above optimum soil $\mathrm{NO}_{3}-\mathrm{N}$, and slightly below optimum soil boron (B). The soil was fumigated with sodium methyldithiocarbamate) (AMVAC, Los Angeles, CA) in fall of 1999, but analyses conducted in 2003 indicated that the replant disease complex was affecting tree vigor at the site despite the earlier fumigation (Mark Mazzola, personal communication). The trees were established and maintained for the first five growing seasons with eight different irrigation and soil management treatments designed to encourage initial tree establishment and performance. A randomized complete block design with six replicate plots of each treatment was established in three long orchard rows. Each plot consisted of four measurement trees bordered at each end by a guard tree. Pertinent to this report was a factorial combination of four treatments involving presence or absence of mulch with or without soil amendment, all of which were under the same irrigation treatment described subsequently. The four treatments considered here included: 1) a control with neither mulch nor amendment; 2) alfalfa hay mulch applied at a rate $\approx 50 \mathrm{t}^{-\mathrm{ha}^{-1}}$ in May 2000 within a $1.5 \mathrm{-m}$ wide strip centered on the row. The mulch was maintained until the 2004 growing season by periodic applications of additional alfalfa each spring to maintain a $10-\mathrm{cm}$ depth; 3 ) a minimally CDS amendment applied at $45 \mathrm{t} \cdot \mathrm{ha}^{-1}$ in May 2000 within the tree row as for the mulch; and 4) a combined mulch and amendment treatment established in May 2000 by applying the CDS beneath the alfalfa mulch. The CDS was obtained from a dairy in the Yakima area. Properties of alfalfa hay and the CDS are presented in Table 1.

For all treatments, irrigation was applied through two $4-\mathrm{L} \cdot \mathrm{h}^{-1}$ pressure-compensating emitters located at $0.3 \mathrm{~m}$ either side of each tree within the row. Irrigation quantity was applied daily in response to the previous day's evapotranspiration demand automatically scheduled by atmometer (Parchomchuk et al., 1996). In Apr. 2000, ammonium polyphosphate $(10 \mathrm{~N}-15 \mathrm{P}-0 \mathrm{~K})$ was fertigated to apply $20 \mathrm{~g} \mathrm{P}$ per tree over a 3 -d period (30 min of fertigation per day). Calcium nitrate $(15.5 \mathrm{~N}-0 \mathrm{P}-0 \mathrm{~K})$ was fertigated daily to apply $20 \mathrm{~g} \mathrm{~N}$ per tree from 17 May to 7 Sept. in 2000 and annually, 2001-04, over an 8-week Vapam (metam sodium, active ingredient

period starting mid-May. Starting in 2002 and annually until $2004,0.17 \mathrm{~g} \mathrm{~B}$ per tree was fertigated over a 4-week period starting in mid-May. Cultural management of the orchard block was undertaken by the cooperating orchardist and followed standard production practices for the region as described in the Crop Production Guide for Tree Fruits in Washington State ( $<$ http://pubs.wsu.edu $>$ ).

Plant responses. Composite samples of 30 leaves from the midportion of extension shoots of the current year's growth were collected from each of the four measurement trees for each experimental plot annually from 2000 to 2004 . All samples were ovendried at $65{ }^{\circ} \mathrm{C}$ and ground in a stainless steel mill. In 2000 and 2001, a 250-mg subsample was digested for $0.75 \mathrm{~h}$ on a block digester at $350{ }^{\circ} \mathrm{C}$ in a $\mathrm{H}_{2} \mathrm{SO}_{4}$ solution containing $\mathrm{K}_{2} \mathrm{SO}_{4}$ and $\mathrm{HgO}$. Nitrogen in the digest was determined through the formation of an ammoniumsalicylate complex and $\mathrm{P}$ was determined through the formation of a phosphomolybdenum blue complex (Technicon Autoanalyzer II Industrial Method No. 334-74 A/A; Technicron, Elmsford, NY). From 2002 to 2004, leaf $\mathrm{N}$ was determined using the LECO FP528 (LECO Corporation, St. Joseph, MI) combustion analyzer. From 2002 to 2004, leaf P was determined on 0.5-g samples, dry-ashed at $525^{\circ} \mathrm{C}$, and dissolved in $1.2 \mathrm{M} \mathrm{HCl}$ before $\mathrm{P}$ determination by inductively coupled argon plasma (ICP) spectrophotometry. $\mathrm{Ca}, \mathrm{Mg}$, and $\mathrm{K}$ were determined on the samples by atomic absorption spectrophotometry and B by ICP spectrophotometry.

Total shoot growth was determined for each measurement tree at harvest in 2000 and 2001. Trunk diameter at $30 \mathrm{~cm}$ above the graft union was measured annually in October and used to calculate annual trunk cross-sectional area (TCSA).

Annual yield and the number of fruit were measured for each experimental plot and replicate from 2001 to 2004 in early October at commercial harvest. Average fruit weight for each plot was calculated from these numbers. A randomly selected 10 apple sample from the midcanopy location for each experimental plot was also evaluated annually for fruit quality characteristics. Flesh firmness was determined with a Baullaf (Lake City Technical Products Ltd., Kelowna, British Columbia, Canada) penetrometer $(11.1-\mathrm{mm}$ diameter tip). An additional random sample of 10 fruit from each plot was collected for mineral analyses. Samples were rinsed under

Table 1. Concentrations of major nutrients in composted dairy manure solids (CDS) amendment and alfalfa hay mulch and estimated total initial nutrient inputs based on bulk application rates of $45 \mathrm{Mg} \cdot \mathrm{ha}^{-1}$ and $50 \mathrm{Mg} \cdot \mathrm{ha}^{-1}$ of CDS and alfalfa at planting, respectively.

\begin{tabular}{|c|c|c|c|c|c|c|c|c|c|}
\hline & $\mathrm{C} / \mathrm{N}$ & $\mathrm{N}$ & $\mathrm{P}$ & $\mathrm{K}$ & $\mathrm{Ca}$ & $\mathrm{Mg}$ & $\mathrm{B}$ & $\mathrm{pH}$ & $\mathrm{EC}$ \\
\hline & & -------- & ----- Perc & ent dry we & ight ------- & -------- & $\left(\mathrm{mg} \cdot \mathrm{kg}^{-1}\right)$ & & $\left(\mathrm{dS} \cdot \mathrm{m}^{-1}\right)$ \\
\hline $\mathrm{CDS}, \mathrm{n}=3$ & 10.6 & 0.90 & 0.59 & 1.91 & 2.42 & 1.05 & 4.3 & 9.2 & 44.3 \\
\hline Alfalfa, $n=90$ & 11.1 & 3.30 & 0.31 & 3.09 & 1.25 & 0.23 & 35.2 & & \\
\hline \multicolumn{10}{|c|}{ Total application $\left(\mathrm{kg} \cdot \mathrm{ha}^{-1}\right)$} \\
\hline $\operatorname{CDS}\left(45 \mathrm{t} \cdot \mathrm{ha}^{-1}\right)$ & & 405 & 266 & 860 & 1089 & 473 & 0.2 & & \\
\hline Alfalfa $\left(50 \mathrm{t} \cdot \mathrm{ha}^{-1}\right)$ & & 1650 & 155 & 1545 & 625 & 150 & 1.8 & & \\
\hline
\end{tabular}

$\mathrm{C}=$ carbon; $\mathrm{N}=$ nitrogen; $\mathrm{P}=$ phosphorus; $\mathrm{K}=$ potassium $; \mathrm{Ca}=$ calcium; $\mathrm{Mg}=$ magnesium; $\mathrm{B}=$ boron; $\mathrm{EC}=$ electrical conductivity. distilled water and then air-dried. Chemical analyses were conducted on a composite of opposite, unpeeled quarters from each apple minus stem tissue and seeds. In 2000 and 2001 , fruit tissue was blended with 1.5 times their weight of distilled water. A $150-\mathrm{mL}$ subsample was further homogenized with a high-speed tissue homogenizer. A weighed 9-mL subsample of homogenized slurry was digested in $5.4 \mathrm{~mL}$ of concentrated $\mathrm{H}_{2} \mathrm{SO}_{4}$ containing $\mathrm{NaSO}_{4}(1.8 \mathrm{~g})$, copper $(0.36 \mathrm{~mL} 25 \%$ $\mathrm{CuSO}_{4}$ solution $)$, and selenium $\left(0.67 \mathrm{~g} \cdot \mathrm{L}^{-1}\right)$ at $380 \%$ for $1 \mathrm{~h}$. Nitrogen and $\mathrm{P}$ were determined by colorimetric methods, as described for leaf samples and $\mathrm{Ca}, \mathrm{Mg}, \mathrm{K}$, and $\mathrm{B}$ were determined by the spectrophotometric methods described for leaves. Starting in 2002, LECO$\mathrm{N}$ was determined on a 0.125 -g subsample of freeze-dried sectors and $\mathrm{Ca}, \mathrm{Mg}$, and $\mathrm{K}$ on a 0.5 -g freeze-dried subsample previously described for leaf samples. All fruit mineral analyses data were expressed on a fresh weight (FW) basis.

Soil sampling and microfaunal analyses. Composite soil samples were taken from each plot in May and Oct. 2000 through 2004. Each sample was composed of eight $15-\mathrm{cm}$ deep cores taken between 15 and $30 \mathrm{~cm}$ from the row middle in the vicinity of the four measurement trees in each plot. Soil samples were passed through a $6-\mathrm{mm}$ sieve, and then Baermann pans ( $16 \mathrm{~cm}$ diameter) were used to extract nematodes from $60-\mathrm{mL}$ subsamples of soil over $7 \mathrm{~d}$ (Forge and Kimpinski, 2007). Total nematodes in the sample were counted at $40 \times$ and then, at $200 \times$ and $400 \times$, the first 100 nematodes observed along random transects through the sample were identified. Most specimens were identified to the genus level during these routine analyses at $400 \times$, but Rhabditids and Diplogasterids were counted at the family level.

The abundance of nematodes in the major functional groups (bacterivorous, fungivorous, omnivorous, predacious) and the abundance of nematodes with "enrichment opportunist" ecological characteristics (as defined by Bongers, 1999) were calculated and data were expressed as nematodes per $100 \mathrm{~g}$ dry soil for each of the groups. The nematode community Structure Index (SI) was calculated for each sample after assigning c-p values to each genus as described by Ferris et al. (2001). Simpson's index of diversity was calculated using genus-level abundance data (Washington, 1984). Protozoa were enumerated using the Most Probable Number technique (Rønn et al., 1995) in October of 2000 and 2001. The assays were performed in 24-well cell culture plates and the growth medium in each well was $0.8 \mathrm{~mL}$ autoclaved soil extract amended with $0.1 \%$ glucose. Four replicate 5-fold dilution series were prepared for each soil sample, starting with an initial 1:50 soil:sterile tap water suspension shaken at $240 \mathrm{rpm}$ for $4 \mathrm{~min}$. The plates were incubated at $20{ }^{\circ} \mathrm{C}$. After $14 \mathrm{~d}$, wells were scored for the presence of naked amoebae and flagellates using an inverted microscope. Tables of Woomer (1994) were used for estimating the most probable number of protozoa per gram of soil 
Table 2. Summary of results of mixed model analysis of variance of annual shoot extension growth (ExtGrth), trunk cross-sectional area (TCSA), fruit yield, and fruit size and firmness.

\begin{tabular}{|c|c|c|c|c|c|c|c|c|c|c|c|c|c|c|}
\hline \multirow[b]{2}{*}{ Variable } & \multicolumn{2}{|c|}{ Mulch (M) } & \multicolumn{2}{|c|}{ Amendment (A) } & \multicolumn{2}{|c|}{$\mathrm{M} \times \mathrm{A}$} & \multicolumn{2}{|c|}{ Yr (Y) } & \multicolumn{2}{|c|}{$M \times Y$} & \multicolumn{2}{|c|}{$A \times Y$} & \multicolumn{2}{|c|}{$\mathrm{M} \times \mathrm{A} \times \mathrm{Y}$} \\
\hline & F-stat & $P$ value & F-stat & $P$ value & F-stat & $P$ value & F-stat & $P$ value & F-stat & $P$ value & F-stat & $P$ value & F-stat & $P$ value \\
\hline \multicolumn{15}{|c|}{ Vegetative growth } \\
\hline th & $7.53\left(1^{z}\right)$ & $<0.0$ & ) & 0.218 & 1) & 0.575 & $5.34(1)$ & $<0.032$ & (1) & $<0.554$ & & 0.437 & (1) & 0.374 \\
\hline \multicolumn{15}{|c|}{ Fruit parameters } \\
\hline Yield & $5.29(1)$ & 0.033 & $59(1)$ & 0.451 & $24(1)$ & 0.279 & $26.53(3)$ & $<0.001$ & $0.57(3)$ & 0.638 & $1.02(3)$ & 0.392 & $0.58(3)$ & 0.634 \\
\hline Size & 31.39 (1) & $<0.001$ & $2.40(1)$ & 0.128 & $.02(1)$ & 0.393 & $131.78(3)$ & $<0.001$ & $1.02(3)$ & 0.393 & $0.69(3)$ & 0.564 & $0.21(3)$ & 0.887 \\
\hline
\end{tabular}

${ }^{\mathrm{z}}$ Values in parentheses are df.

from the number of positive replicate wells at each dilution.

In 2004, root fragments were collected from each sample as it was sieved, and the root fragments were separated into greater than $2 \mathrm{~mm}$ and less than $2 \mathrm{~mm}$ diameter size fractions. The less than $2 \mathrm{~mm}$ diameter root fragments were chopped into 1 - to 2-cm long pieces, washed over a $250-\mu \mathrm{m}$ sieve with a stream of water, and subjected to root-lesion nematode extraction in a mist chamber for $7 \mathrm{~d}$ (Ingham, 1994). After nematode extraction, the root samples were air-dried and weighed. Soil samples collected Oct. 2004 were airdried and subjected to a broad set of chemical analyses at a commercial laboratory (Norwest Laboratories, Lethbridge, Alberta, Canada).

All plant measurements and nematode community parameters were analyzed using a mixed model analysis of variance (ANOVA) for a randomized complete block design (PROC MIXED) in SAS (SAS Institute Inc., 2000). The ANOVA model had blocks as a random effects factor, mulch (present or absent) and amendment (present or absent) as fixed effects factors, and sample date or year factors were treated as repeated measures using the REPEATED statement in PROC MIXED. When main factor effects of mulch or amendment or their interaction with sample date were significant, the SLICE procedure was used to test the significance of differences between treatments at individual sample dates. Root-lesion nematode data were logtransformed before analysis to minimize heteroscedasticity. Soil chemical properties and cumulative yield were analyzed using PROC GLM for a two-factor randomized complete block experimental design.

\section{Results and Discussion}

\section{Crop response}

Alfalfa mulch had strong effects on tree growth and yield, significantly increasing leader growth in each of the first 2 years and increasing TCSA in all years (Tables 2 and 3 ). CDS amendment did not affect tree growth and yield (data not shown). There was a tendency for slightly stronger effect of mulch on TCSA in plots without the CDS amendment, which was manifest as a significant interaction between mulch and amendment (Tables 2 and 3). Mulch increased individual-year apple yields (main factor effect of mulch, Table 2) and cumulative yield for the period 200104 (Table 4). Mulch also increased fruit size

Table 3. Effects of alfalfa hay mulch and composted dairy manure solids amendment on vigor of 'Braeburn' apple on M.9, 2000-05.

\begin{tabular}{lccccc}
\hline & \multicolumn{2}{c}{ Extension growth $(\mathrm{cm})$} & & \multicolumn{2}{c}{ Trunk cross-sectional area $\left(\mathrm{cm}^{2}\right)$} \\
\cline { 2 - 3 } \cline { 5 - 6 } Yr & No mulch & Mulch & & No mulch & Mulch \\
\hline 2000 & 152 & $235^{*}$ & & 3.06 & $3.54^{*}$ \\
2001 & 229 & $377^{*}$ & & 3.93 & $4.81^{* * *}$ \\
2002 & ND & ND & & 5.27 & $6.14^{* * *}$ \\
2003 & ND & ND & & 5.79 & $7.16^{* * *}$ \\
2004 & ND & ND & & 6.72 & $8.47^{* * *}$ \\
Mean & 190 & $306^{*}$ & & 4.95 & $6.02^{* * *}$ \\
M $\times$ A interaction effect & & & & \\
No amendment & NS & NS & & 4.81 & $6.30^{* * *}$ \\
Amendment & NS & NS & 5.09 & $5.74^{*}$ \\
\hline
\end{tabular}

$*, * *$, and $* * *$ denote means significantly different at $P<0.05,0.01$, or 0.001 , respectively.

$\mathrm{ND}=$ not determined; $\mathrm{NS}=$ nonsignificant mulch $\times$ amendment interaction .

Table 4. Effects of alfalfa hay mulch on yield and fruit size and firmness of 'Braeburn' apple on M.9, 2001-04.

\begin{tabular}{|c|c|c|c|c|c|c|}
\hline \multirow[b]{2}{*}{ Yr } & \multicolumn{2}{|c|}{ Yield (kg/tree) } & \multicolumn{2}{|c|}{ Fruit size $(\mathrm{g})$} & \multicolumn{2}{|c|}{ Firmness (N) } \\
\hline & No mulch & $\overline{\text { Mulch }}$ & No mulch & Mulch & No mulch & Mulch \\
\hline$\overline{2001}$ & 2.16 & 2.37 & 277 & 289 & 90.5 & 91.3 \\
\hline 2002 & 4.23 & 5.16 & 204 & 212 & 93.2 & 92.3 \\
\hline 2003 & 4.11 & $5.46^{*}$ & 190 & $214 * *$ & 90.0 & $85.4 * *$ \\
\hline 2004 & 5.91 & 6.56 & 181 & $200 *$ & 91.2 & 90.4 \\
\hline Mean & & & 213 & $229 * * *$ & 91.2 & 89.9 \\
\hline Cumulative & 16.41 & $19.55^{* *}$ & & & & \\
\hline
\end{tabular}

(Tables 2 and 4) and caused a modest reduction in fruit firmness in 2003 (Table 4). Fruit color, juice solute solids, and titratable acidity were unaffected by mulching and amendment (data not shown).

Mulches can improve tree vigor, yield, and fruit size by several means including improved water availability (Cline et al., 2011), either improved nutrient availability or capacity to access nutrients (Neilsen et al., 2003a), and beneficial changes in soil biology and root-microbe interactions (Forge et al., 2003, 2008; Forge and Kempler, 2009). There have been few assessments of effects of mulching on fruit quality (Hogue and Neilsen, 1987). Data from this study would suggest there would be no major concerns regarding fruit quality as a consequence of the mulching strategy used in this experiment.

\section{Soil and plant nutrients}

The major plant nutrients contained within both the CDS amendment and alfalfa mulch represented potentially significant additions of $\mathrm{N}, \mathrm{P}, \mathrm{K}, \mathrm{Ca}$, and $\mathrm{Mg}$ to root zone soil. The alfalfa mulch contained more $\mathrm{N}$ and $\mathrm{K}$, whereas the CDS amendment was more enriched in P, $\mathrm{Ca}$, and $\mathrm{Mg}$ (Table 1). Influences of the mulch and amendment on soil fertility persisted into the fifth year of the study (Table 5). Both materials increased soil organic matter content, electrical conductivity, and extractable $\mathrm{NH}_{4}-\mathrm{N}$ to similar degrees. The amendment increased $\mathrm{pH}$ and extractable $\mathrm{Mg}$ and $\mathrm{Ca}$, whereas the mulch did not significantly affect these parameters. The amendment also increased extractable $\mathrm{P}$ and $\mathrm{K}$ by $360 \%$ and $185 \%$, respectively, whereas the mulch increased extractable $\mathrm{P}$ and $\mathrm{K}$ by $150 \%$ and $220 \%$, respectively. Extractable $\mathrm{NH}_{4}-\mathrm{N}$ and $\mathrm{NO}_{3}-\mathrm{N}$ were both substantially elevated under mulch. As highly dynamic pools of soil $\mathrm{N}$, these single point-in-time measurements of $\mathrm{NH}_{4}-\mathrm{N}$ and $\mathrm{NO}_{3}-\mathrm{N}$ are of limited value for explaining differences in cumulative plant $\mathrm{N}$ uptake and growth, but their relative increase indicates enhanced $\mathrm{N}$ mineralization under the alfalfa mulch through 2004.

Tissue nitrogen. Increased leaf $\mathrm{N}$ concentration was associated with alfalfa mulch application (Tables 6 and 7). Increases were modest despite a significant pool of $\mathrm{N}$ contained within the mulch. Similarly, application of CDS amendment modestly affected leaf $\mathrm{N}$ (Table 6), increasing the main factor mean from 27.8 to $28.4 \mathrm{~g} \cdot \mathrm{kg}^{-1}$ dry weight. A pattern 
of minimal but positive $\mathrm{N}$ effect of mulch was also apparent in fruit (Table 6). In general, $\mathrm{N}$ status was considered sufficient according to local leaf standards, regardless of treatment, with the lowest leaf $\mathrm{N}$ concentration measured in the non-mulched treatments at $25.5 \mathrm{~g} \cdot \mathrm{kg}^{-1}$ in 2004 . Furthermore, all plots were fertigated with $20 \mathrm{~g} \mathrm{~N}$ per tree annually over an 8-week period as calcium nitrate. The cumulative evidence therefore suggests that the modest augmentation of $\mathrm{N}$ nutrition associated with alfalfa mulch and CDS amendment was unlikely to have been the cause of improved vigor and yield associated with mulch and may also account for the lack of treatment effect on fruit color, which is usually associated with high $\mathrm{N}$ application rate. Similar minimal response of $\mathrm{N}$-fertigated trees to $\mathrm{N}$ applied with biosolids has previously been reported (Neilsen et al., 2007). Our data suggest, however, that it may be possible to substantially reduce fertilizer inputs when alfalfa hay is used as mulch.

Tissue phosphorus. Tree $\mathrm{P}$ uptake was most affected by CDS amendment (Table 6), which increased leaf $\mathrm{P}$ concentration in 4 of 5 years (Table 7 ) and fruit $P$ concentration in all 4 years (Table 8 ). Mulch caused a modest additional increase in leaf $\mathrm{P}$ (Table 6). The differential uptake of $\mathrm{P}$ among treatments

Table 5. Effects of composted dairy manure solids amendment and alfalfa hay mulch on selected soil chemical properties under 'Braeburn' apple on M.9, Oct. 2004.

\begin{tabular}{|c|c|c|c|c|c|c|c|c|c|}
\hline \multirow[b]{2}{*}{ Treatment } & \multirow{2}{*}{$\frac{\mathrm{OM}}{(\%)}$} & \multirow[b]{2}{*}{$\mathrm{pH}$} & \multirow{2}{*}{$\frac{\mathrm{EC}}{\left(\mathrm{dS} \cdot \mathrm{m}^{-1}\right)}$} & \multicolumn{6}{|c|}{ Extractable nutrients $\left(\mathrm{mg} \cdot \mathrm{kg}^{-1}\right)^{\mathrm{z}}$} \\
\hline & & & & $\overline{\mathrm{NH}_{4}-\mathrm{N}}$ & $\mathrm{NO}_{3}-\mathrm{N}$ & $\mathrm{P}$ & $\mathrm{K}$ & $\mathrm{Ca}$ & $\mathrm{Mg}$ \\
\hline No mulch & 1.60 & 6.82 & 0.46 & 5.68 & 22.8 & 170 & 597 & 2719 & 385 \\
\hline Mulch (M) & 1.88 & 6.88 & 0.83 & 10.7 & 69.8 & 251 & 1315 & 2573 & 397 \\
\hline Significance & $*$ & NS & $* * *$ & $* *$ & $* *$ & $* *$ & $* * * *$ & NS & NS \\
\hline No amendment & 1.55 & 6.57 & 0.49 & 6.31 & 39.0 & 92 & 672 & 2493 & 243 \\
\hline Amendment (A) & 1.93 & 7.13 & 0.80 & 10.1 & 53.7 & 330 & 1240 & 2799 & 539 \\
\hline Significance & $* *$ & $* * * *$ & $* *$ & $*$ & NS & $* * * *$ & $* * * *$ & $*$ & $* *$ \\
\hline $\mathrm{M} \times \mathrm{A}$ & NS & NS & NS & NS & NS & NS & NS & NS & NS \\
\hline
\end{tabular}

${ }^{\mathrm{z}} \mathrm{NH}_{4}-\mathrm{N}$ and $\mathrm{NO}_{3}-\mathrm{N}$ extracted with $2.0 \mathrm{M} \mathrm{KCl}$; P extracted with modified Kelowna extractant; $\mathrm{K}, \mathrm{Ca}$, and $\mathrm{Mg}$ extracted in ammonium acetate.

$*, * *, * * *$, and $* * * *$ denote means significantly different at $P \leq 0.05,0.01,0.001$, or 0.0001 , respectively, or not significantly different (NS).

$\mathrm{OM}=$ organic matter; $\mathrm{EC}=$ electrical conductivity $\mathrm{P}=$ phosphorus; $\mathrm{K}=$ potassium $; \mathrm{Ca}=$ calcium; $\mathrm{Mg}=$ magnesium.

reflected the higher $\mathrm{P}$ inputs associated with the CDS amendment (Table 1) and the highest available soil $P$ values for CDS-amended soils at the end of the experiment (Table 5). Application of monoammonium phosphate in the planting hole has been shown to stimulate apple tree growth in old orchard soils (Neilsen and Yorston, 1991) and was the rationale for fertigation of ammonium polyphosphate to all treatments in this experiment in Year 1. Highest leaf $\mathrm{P}$ concentrations were measured in the first year, but midsummer leaf P concentrations, regardless of treatment, generally exceeded $1.5 \mathrm{~g} \mathrm{P} / \mathrm{kg}$ values normally considered adequate for apples (Shear and Faust, 1980). Much less is understood about desirable fruit $\mathrm{P}$ concentrations, but in 2004, fruit $\mathrm{P}$ concentrations from unmulched and unamended trees dropped below values of 8.0 mg P/100 g FW. Recent research on several apple cultivars other than 'Braeburn' recommended harvest fruit $\mathrm{P}$ concentrations of 10 to $12 \mathrm{mg} / 100 \mathrm{~g} \mathrm{FW}$ to optimize fruit quality (Neilsen et al., 2008). The lack of response of 'Braeburn' fruit quality to higher $\mathrm{P}$ regimes associated with the CDS amendment (Table 4) implies the $P$ concentrations measured in our study were generally sufficient for all treatments. Nevertheless, CDS would be an effective source of $\mathrm{P}$ in apple orchards where $\mathrm{P}$ nutrition is a concern.

Tissue potassium, magnesium, and calcium. Potassium nutrition was strongly influenced by application of both alfalfa mulch and

Table 6. Summary of results of mixed model analysis of variance of $\mathrm{N}, \mathrm{P}, \mathrm{K}, \mathrm{Mg}$, and Ca concentrations in leaf and fruit tissues.

\begin{tabular}{|c|c|c|c|c|c|c|c|c|c|c|c|c|c|c|}
\hline & \multicolumn{2}{|c|}{ Mulch } & \multicolumn{2}{|c|}{ Amendment } & \multicolumn{2}{|c|}{$\mathrm{M} \times \mathrm{A}$} & \multicolumn{2}{|c|}{ Date } & \multicolumn{2}{|c|}{$\mathrm{M} \times \mathrm{D}$} & \multicolumn{2}{|c|}{$A \times D$} & \multicolumn{2}{|c|}{$\mathrm{M} \times \mathrm{A} \times \mathrm{D}$} \\
\hline & F-stat & $P$ value & F-stat & $P$ value & F-stat & $P$ value & F-stat & $P$ value & F-stat & $P$ value & F-stat & $P$ value & F-stat & $P$ value \\
\hline \multicolumn{15}{|c|}{ Leaf nutrients } \\
\hline & $\left(1 \mathrm{df}^{z}\right)$ & & $(1 \mathrm{df})$ & & $(1 \mathrm{df})$ & & $(4 \mathrm{df})$ & & $(4 \mathrm{df})$ & & $(4 \mathrm{df})$ & & $(4 \mathrm{df})$ & \\
\hline $\mathrm{N}$ & 13.38 & $<0.001$ & 6.81 & 0.013 & 0.91 & 0.345 & 24.70 & $<0.001$ & 0.60 & 0.662 & 0.40 & 0.806 & 0.32 & 0.866 \\
\hline $\mathrm{P}$ & 2.13 & 0.157 & 51.02 & $<0.001$ & 3.17 & 0.088 & 111.39 & $<0.001$ & 0.41 & 0.798 & 3.58 & 0.010 & 0.29 & 0.887 \\
\hline $\mathrm{K}$ & 138.59 & $<0.001$ & 105.49 & $<0.001$ & 22.30 & $<0.001$ & 253.40 & $<0.001$ & 4.45 & 0.003 & 2.87 & 0.289 & 0.88 & 0.479 \\
\hline $\mathrm{Mg}$ & 25.36 & $<0.001$ & 1.10 & 0.305 & 4.03 & 0.055 & 6.80 & $<0.001$ & 5.20 & 0.001 & 1.31 & 0.275 & 0.88 & 0.480 \\
\hline $\mathrm{Ca}$ & 15.57 & $<0.001$ & 33.51 & $<0.001$ & 3.06 & 0.087 & 83.04 & $<0.001$ & 5.85 & $<0.001$ & 1.54 & 0.211 & 0.36 & 0.837 \\
\hline \multicolumn{15}{|c|}{ Fruit nutrients } \\
\hline $\mathrm{N}$ & 2.97 & 0.098 & 2.28 & 0.145 & 1.12 & 0.302 & 42.80 & $<0.001$ & 1.44 & 0.243 & 1.59 & 0.202 & 1.07 & 0.368 \\
\hline $\mathrm{P}$ & 5.83 & 0.024 & 18.83 & $<0.001$ & 0.41 & 0.527 & 29.56 & $<0.001$ & 0.25 & 0.863 & 0.25 & 0.863 & 0.75 & 0.526 \\
\hline $\mathrm{K}$ & 29.81 & $<0.001$ & 17.03 & $<0.001$ & 0.85 & 0.363 & 29.83 & $<0.001$ & 0.16 & 0.922 & 1.09 & 0.366 & 0.64 & 0.589 \\
\hline $\mathrm{Mg}$ & 1.64 & 0.214 & 8.43 & 0.008 & 0.15 & 0.707 & 17.84 & $<0.001$ & 0.54 & 0.660 & 0.85 & 0.471 & 0.37 & 0.778 \\
\hline $\mathrm{Ca}$ & 9.36 & 0.005 & 12.80 & $<0.001$ & 6.27 & 0.019 & 31.80 & $<0.001$ & 0.86 & 0.468 & 0.27 & 0.847 & 1.55 & 0.213 \\
\hline
\end{tabular}

${ }^{\mathrm{z}}$ Values in parentheses are $\mathrm{df}$

$\mathrm{N}=$ nitrogen; $\mathrm{P}=$ phosphorus $\mathrm{K}=$ potassium; $\mathrm{Mg}=$ magnesium; $\mathrm{Ca}=$ calcium.

Table 7. Effects of alfalfa hay mulch (N, K, Mg, Ca) and composted dairy manure solids amendment (P) on leaf N, P, K, Mg, and Ca of 'Braeburn' apple on M.9, 2000-04.

\begin{tabular}{|c|c|c|c|c|c|c|c|c|c|c|}
\hline \multirow[b]{2}{*}{$\mathrm{Yr}$} & \multicolumn{2}{|c|}{$\mathrm{N}\left(\mathrm{g} \cdot \mathrm{kg}^{-1} \mathrm{DW}\right)$} & \multicolumn{2}{|c|}{$\mathrm{P}\left(\mathrm{g} \cdot \mathrm{kg}^{-1} \mathrm{DW}\right)$} & \multicolumn{2}{|c|}{$\mathrm{K}\left(\mathrm{g} \cdot \mathrm{kg}^{-1} \mathrm{DW}\right)$} & \multicolumn{2}{|c|}{$\mathrm{Mg}\left(\mathrm{g} \cdot \mathrm{kg}^{-1} \mathrm{DW}\right)$} & \multicolumn{2}{|c|}{$\mathrm{Ca}\left(\mathrm{g} \cdot \mathrm{kg}^{-1} \mathrm{DW}\right)$} \\
\hline & No mulch & Mulch & No amendment & Amendment & No mulch & Mulch & No mulch & Mulch & No mulch & Mulch \\
\hline 2000 & 27.7 & 28.0 & 2.00 & $2.33^{* * *}$ & 23.3 & 24.2 & 2.62 & 2.49 & 9.18 & 9.67 \\
\hline 2001 & 28.5 & 29.3 & 1.78 & 1.87 & 22.8 & 26.1 & 2.26 & 2.12 & 9.68 & 9.67 \\
\hline 2002 & 27. & 28.9 & 1.58 & $1.81 * * *$ & 20.8 & 23.8 & 2.32 & 2.08 & 12.06 & $10.68 * *$ \\
\hline 2003 & 28.5 & $30.0 * *$ & 1.65 & $1.95 * * *$ & 19.3 & 22.7 & 2.41 & $2.13^{*}$ & 13.28 & $12.22 *$ \\
\hline 2004 & 25.5 & 26.2 & 1.22 & $1.38 *$ & 12.5 & 16.0 & 2.63 & $1.83 * * *$ & 14.35 & $12.74 * * *$ \\
\hline Mean & 27.6 & $28 * * * *$ & 1.66 & $1.86^{* * *}$ & 19.7 & 22.5 & 2.45 & 2.13 & 11.71 & 11.00 \\
\hline \multicolumn{11}{|c|}{$\mathrm{M} \times \mathrm{A}$ interaction effect } \\
\hline No amendment & NS & NS & NS & NS & 1.793 & $2.188 * * *$ & NS & NS & NS & NS \\
\hline Amendment & NS & NS & NS & NS & 2.152 & $2.320 * * *$ & NS & NS & NS & NS \\
\hline
\end{tabular}

$*, * *$, and $* * *$ denote means significantly different at $P \leq 0.05,0.01$, or 0.001 , respectively; ns $=$ no significant mulch $\times$ amendment interaction term.

$\mathrm{N}=$ nitrogen; $\mathrm{P}=$ phosphorus; $\mathrm{K}=$ potassium; $\mathrm{Mg}=$ magnesium; $\mathrm{Ca}=$ calcium; $\mathrm{DW}=$ dry weight 
Table 8. Effects of alfalfa hay mulch (N, K, Ca) and composted dairy manure solids amendment (P, Mg) on fruit N, P, K, Mg, and Ca of 'Braeburn' apple on M.9, 2001-04.

\begin{tabular}{|c|c|c|c|c|c|c|c|c|c|c|}
\hline \multirow[b]{2}{*}{$\mathrm{Yr}$} & \multicolumn{2}{|c|}{$\mathrm{N}(\mathrm{mg} / 100 \mathrm{~g} \mathrm{FW})$} & \multicolumn{2}{|c|}{$\mathrm{P}(\mathrm{mg} / 100 \mathrm{~g} \mathrm{FW})$} & \multicolumn{2}{|c|}{$\mathrm{K}(\mathrm{mg} / 100 \mathrm{~g} \mathrm{FW})$} & \multicolumn{2}{|c|}{$\mathrm{Mg}(\mathrm{mg} / 100 \mathrm{~g} \mathrm{FW})$} & \multicolumn{2}{|c|}{$\mathrm{Ca}(\mathrm{mg} / 100 \mathrm{~g} \mathrm{FW})$} \\
\hline & No mulch & $\overline{\text { Mulch }}$ & No amendment & Amendment & No mulch & $\overline{\text { Mulch }}$ & No amendment & Amendment & No mulch & Mulch \\
\hline$\overline{2001}$ & 72.1 & 74.4 & 10.96 & $12.03^{*}$ & 148.5 & 160.9 & 6.17 & 6.40 & 2.98 & 2.66 \\
\hline 2002 & 61.4 & 60.9 & 9.03 & $10.16^{*}$ & 138.3 & 154.6 & 5.79 & 6.12 & 4.51 & 4.34 \\
\hline 2003 & 64.6 & 65.7 & 7.97 & $9.45 * *$ & 135.5 & 150.1 & 5.72 & 5.80 & 3.78 & 3.57 \\
\hline 2004 & 50.6 & 57.2 & 7.43 & $9.06 * *$ & 112.2 & 129.3 & 4.96 & $5.50 * *$ & 4.05 & 3.40 \\
\hline Mean & 62.2 & 64.6 & 8.85 & $10.18 * * *$ & 133.6 & 148.7 & 5.66 & $5.96 * *$ & 3.83 & 3.49 \\
\hline \multicolumn{11}{|c|}{$\mathrm{M} \times \mathrm{A}$ interaction effect } \\
\hline No amendment & NS & NS & NS & NS & NS & NS & NS & NS & 4.167 & $3.551 * * *$ \\
\hline Amendment & NS & NS & NS & NS & NS & NS & NS & NS & 3.494 & 3.433 \\
\hline
\end{tabular}

$*, * *$, and *** denote means significantly different at $P \leq 0.05,0.01$, or 0.001 , respectively; ns $=$ no significant mulch $\times$ amendment interaction term.

$\mathrm{N}=$ nitrogen; $\mathrm{P}=$ phosphorus; $\mathrm{K}=$ potassium; $\mathrm{Mg}=$ magnesium; $\mathrm{Ca}=$ calcium; $\mathrm{FW}=$ fresh weight

CDS amendment. There was a significant mulch $\times$ amendment interaction for leaf $\mathrm{K}$ (Table 6) with leaf $\mathrm{K}$ increased in trees grown with mulch but with increases less pronounced in trees also receiving amendment (Table 7). Both mulch and CDS amendment increased fruit $\mathrm{K}$ to similar degrees (Tables 6 and 8). The increases in plant $\mathrm{K}$ status associated with both alfalfa mulch and CDS amendment are consistent with the increased extractable K content of soil measured for both treatments by the end of the experiment in 2004 (Table 5). Improvements in plant $\mathrm{K}$ status were sometimes associated with a decline in leaf and fruit $\mathrm{Mg}$ and $\mathrm{Ca}$ concentration. Decreased leaf $\mathrm{Mg}$ concentration was particularly associated with mulch (Tables 6 and 7). Fruit Mg concentration was unaffected by mulch but was higher for trees to which CDS was applied (Tables 6 and 8). Collectively the $\mathrm{Mg}$ results are consistent with increased soil-extractable $\mathrm{Mg}$ status measured for CDS-amended but not mulched soils by 2004 (Table 5). Leaf Ca concentration was decreased by both mulch and amendment (Tables 6 and 7). There was a significant mulch $\times$ amendment interaction for fruit $\mathrm{Ca}$ (Table 6) with mulch only causing a significant reduction in trees that had not been treated with CDS amendment (Table 8). These plant Ca results were independent of soil Ca status, which was unaffected by mulch and had a modest increase as a result of CDS application (Table 5).

Changes in leaf $\mathrm{K}, \mathrm{Mg}$, and $\mathrm{Ca}$ status observed during the study did not result in deficient levels of these nutrients (Shear and Faust, 1980) and hence were unlikely explanations for the improved yield and vigor associated with mulching. Improvements in leaf $\mathrm{K}$ as a result of alfalfa mulch are consistent with previous reports (Hogue and Neilsen, 1987; Neilsen et al., 2003a, 2003b) and imply that both alfalfa and CDS would be valuable additions for sites with low soil K. Magnesium nutrition was a concern of the cooperating grower at this site as indicated by the application of several foliar $\mathrm{Mg}$ applications in the block during the study. This may have overridden potential negative consequences to decreased leaf $\mathrm{Mg}$ associated with mulch because mulched trees grew better. High application of soil $\mathrm{K}$ and $\mathrm{Mg}$ to soil have been cited as a potential concern for fruit $\mathrm{Ca}$ accumulation and hence fruit quality (Faust, 1989). Both alfalfa mulch and CDS amendment were effective sources of either K (both) or $\mathrm{Mg}(\mathrm{CDS})$ and were sometimes associated

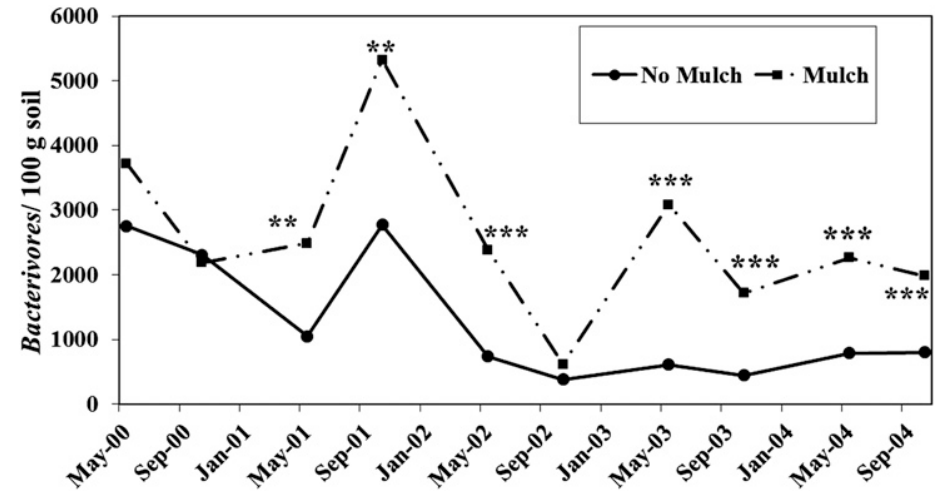

Fig. 1. Effect of alfalfa hay mulch on temporal dynamics of bacterivorous nematode population densities in soil. Points labeled with *,**, or *** denote that the main factor effect of mulch was significant at $P \leq$ $0.05,0.01$, or 0.001 , respectively.

with decreased fruit Ca concentration. However, in years $(2001,2003$, and 2004) when fruit $\mathrm{Ca}$ concentration was below the critical $4.0 \mathrm{mg} \mathrm{Ca} / 100 \mathrm{~g} \mathrm{FW}$ threshold (Neilsen and Neilsen, 2003), all treatments in general had low $\mathrm{Ca}$. Thus, effective foliar $\mathrm{Ca}$ applications would have been recommended for the whole block regardless of mulch or amendment treatment (Peryea et al., 2007). This was also consistent with the lack of fruit quality effects associated with treatments.

\section{Soil microfauna}

Bacterivorous nematodes were $\approx 20 \times$ more abundant than other trophic groups, and the bacterivorous nematode community was in turn dominated (greater than $90 \%$ ) by members of the Rhabditida classified as enrichment opportunists (Bongers, 1999). Consequently, the responses to mulch of total free-living nematodes and the enrichment opportunist functional group mirrored total bacterivores (Fig. 1). There were significant mulch $\times$ sample date and amendment $\times$ sample date interaction effects on bacterivorous nematode abundance (Table 9) with significantly greater population densities under mulch at seven of 10 sample dates (Fig. 1). There were significant main factor effects of both mulch and amendment on the abundance of fungivorous nematodes (Table 9) with amendment and mulch suppressing main factor mean population densities from 134 to 81 nematodes/ $100 \mathrm{~g}$ soil and from 128 to 86 nematodes $/ 100 \mathrm{~g}$ soil, respectively.

Populations of protozoa responded positively to both mulch and amendment (mulch $\times$ amendment interaction) with population densities in the combined application being no greater than in the mulch-only or amendment-only treatments (Table 10).

Increased populations of microbivorous nematodes and protozoa are indicative of overall increased soil microbial activity and nutrient mineralization. Increased microbial biomass production drives population growth of the microbivorous microfauna and increased grazing by the microfauna in turn stimulates mineralization of nutrients tied up in the microbial biomass (Bonkowski et al., 2009). Accordingly, the abundance or relative dominance of bacterivores or enrichment opportunists has been correlated with $\mathrm{N}$ mineralization across sites (Forge and Simard, 2001; Hassink et al., 1993; Parfitt et al., 2005) and across organic amendment treatments (Ferris and Matute, 2003). Rhizosphere grazing by microbivorous nematodes can also stimulate root growth independently of nutrient supply (Bonkowski et al., 2009). The bacterivorous nematode data indicate that alfalfa hay mulch sustained high levels of microbial activity and nutrient mineralization, which is consistent with the increased $\mathrm{NH}_{4}-\mathrm{N}$ and $\mathrm{NO}_{3}-\mathrm{N}$ levels under mulch in late 2004.

Root-lesion nematode population densities were initially very small as a result of the preplant fumigation, but they increased more rapidly in non-mulched plots than in mulched plots (Fig. 2). There were no significant effects of amendment or amendment $\times$ mulch interaction on root-lesion nematode population densities (Table 9). From Oct. 2002 through 
Table 9. Summary of results of mixed model analysis of variance of soil nematode parameters.

\begin{tabular}{|c|c|c|c|c|c|c|c|c|c|c|c|c|c|c|}
\hline \multirow[b]{2}{*}{ Variable } & \multicolumn{2}{|c|}{ Mulch $\left(1 \mathrm{df}^{z}\right)$} & \multicolumn{2}{|c|}{ Amendment (1 df) } & \multicolumn{2}{|c|}{$M \times A(1 \mathrm{df})$} & \multicolumn{2}{|c|}{ Date $(9 \mathrm{df})$} & \multicolumn{2}{|c|}{$M \times D(9 d f)$} & \multicolumn{2}{|c|}{$A \times D(9 d f)$} & \multicolumn{2}{|c|}{$M \times A \times D(9 d f)$} \\
\hline & F-stat & $P$ value & F-stat & $P$ value & F-stat & $P$ value & F-stat & $P$ value & F-stat & $P$ value & F-stat & $P$ value & F-stat & $P$ value \\
\hline $\mathrm{BN}$ & 56.06 & $<0.001$ & 4.15 & 0.047 & 2.69 & 0.107 & 14.94 & $<0.001$ & 2.49 & 0.011 & 3.27 & 0.001 & 1.52 & 0.147 \\
\hline SI & 3.83 & 0.055 & 1.52 & 0.223 & 0.01 & 0.924 & 34.19 & $<0.001$ & 1.87 & 0.059 & 2.33 & 0.017 & 2.85 & 0.004 \\
\hline Simp & 111.10 & $<0.001$ & 4.76 & 0.033 & 1.89 & 0.174 & 13.10 & $<0.001$ & 6.26 & $<0.001$ & 1.74 & 0.083 & 0.92 & 0.506 \\
\hline
\end{tabular}

${ }^{\mathrm{z}}$ Values in parentheses are $\mathrm{df}$.

${ }^{\mathrm{y}}$ Transformed to $\log (\mathrm{X}+100)$ before analysis.

$\mathrm{Pp}=$ Pratylenchus penetrans $; \mathrm{BN}=$ bacterivorous nematodes; $\mathrm{FN}=$ fungivorous nematodes; $\mathrm{OPN}=$ omnivorous and predacious nematodes; $\mathrm{SI}=$ nematode community Structure Index; Simp = Simpson's index of diversity.

Table 10. Effects of composted dairy manure solids amendment and alfalfa hay mulch on population densities of total soil protozoa (log-protozoa/ gram dry soil) in soil under 'Braeburn' apple on M.9.

\begin{tabular}{lcc}
\hline & No mulch & Mulch \\
\hline No amendment & $4.71^{* * *}$ & 5.26 \\
Amendment & 5.43 & 5.41 \\
Analysis of variance summary & \\
$P$ (amendment) & $<0.001$ & \\
$P($ mulch $)$ & 0.015 & \\
$P(\mathrm{M} \times \mathrm{A})$ & 0.009 & \\
\hline
\end{tabular}

${ }^{\mathrm{z} A m e n d m e n t} \times$ date, mulch $\times$ date, and amendment $\times$ mulch $\times$ date interactions were not significant and are not presented.

$*, * *$, and $* * *$ denote means significantly different from other treatment combinations at $P \leq 0.05$, 0.01 , or 0.001 , respectively.

2004, soil population densities in nonmulched plots were significantly greater than under mulch at most sample dates (Fig. 2). Population densities in roots were only assessed in 2004, when there was a significant main factor effect of mulch $(P=0.05)$ with 285 nematodes per gram root in non-mulched plots and 142 nematodes per gram root in mulched plots. These results are consistent with earlier experiments with alfalfa hay mulch (Forge et al., 2003) and suggest that differential early buildup of root-lesion nematode populations and perhaps other root pathogens could have contributed to the differential vigor in mulched and non-mulched plots. Other plant parasites included Paratrichodorus, Hemicycliophora, and Paratylenchus. Populations of these nematodes also increased in later years of the experiment, but they were more patchily distributed among plots and there were no consistent effects of mulch or amendment on their population growth (data not shown).

Although the research site was fumigated in fall of 1999, the trees appeared to be affected by the replant disease complex. Seedlings grown in steam-pasteurized soil collected from the site in 2003 were more vigorous than seedlings grown in non-pasteurized soil, and fungi typically associated with root-lesion nematodes in the replant disease complex (Rhizoctonia, Pythium, and Cylindrocarpon) were isolated from roots of seedlings grown in non-pasteurized soil (Mark Mazzola, personal communication). Because root-lesion nematodes are an important component of the replant disease complex, we speculate that

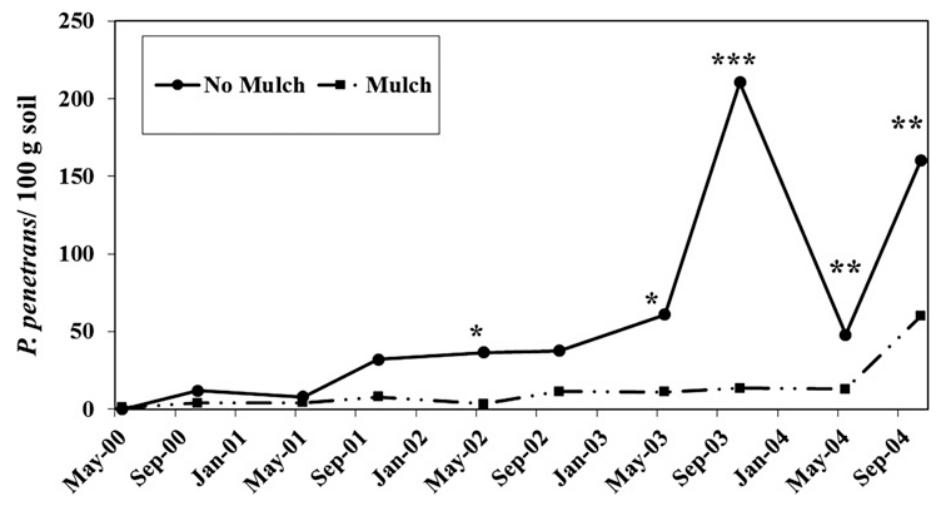

Fig. 2. Effect of alfalfa hay mulch on temporal dynamics of Pratylenchus penetrans population densities in soil. Points labeled with *,**, or *** denote that main factor effect of mulch was significant at $P \leq$ $0.05,0.01$, or 0.001 , respectively, from analysis of variance of log-transformed data.

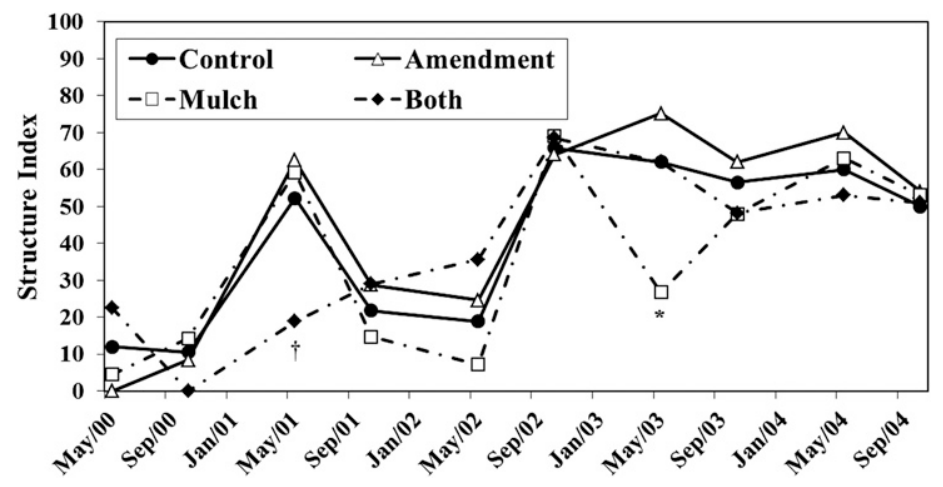

Fig. 3. Effect of alfalfa hay mulch on temporal dynamics of the nematode community Structure Index. $\dagger$ Mulch $\times$ amendment interaction $P=0.01$; *Main factor effect of mulch $(P=0.007)$ and amendment $(P=0.007)$.

suppression of root-lesion nematode population growth under mulch helped alleviate replant stress, resulting in improved vigor of trees grown under mulch. Future research should address effects of alfalfa mulch on fungal pathogens as well as root-lesion nematodes.

Many types of organic amendments and mulches have been observed to suppress populations of plant-parasitic nematodes in a variety of agroecosystems (Akhtar and Malik, 2000; McSorley, 2011; Oka, 2010) including apple orchards (Forge et al., 2003, 2008; Stirling et al., 1995). Organic matter inputs stimulate population growth or activity of a broad range of organisms in the soil food web, some of which are potential predators or parasites of plant-parasitic nematodes
(McSorley, 2011). Ferris et al. (2001) proposed the nematode community SI as an indicator of the structure of soil food webs, and suppression of plant-parasitic nematodes has been correlated with the SI (Ferris et al., 2012; Sanchez-Moreno and Ferris, 2007). In our study, the SI increased in all treatments as the complexity of the soil food web developed after fumigation (Fig. 3), but its relationship with mulch and amendment treatment was inconsistent (date $\times$ mulch $\times$ amendment interaction; Table 9) and it was not inversely correlated across treatments with root lesion nematode population growth. A complementary measure of food web complexity, Simpson's index of diversity, increased in non-mulched plots but remained low in 
mulched plots (date $\times$ mulch interaction $P<$ 0.001 ; data not shown) and also was not inversely correlated with root-lesion nematode population growth. We conclude that the suppression of root-lesion nematode population growth in mulched plots was not related to enhanced food web structure as measured through the SI or Simpson's index of diversity.

\section{Conclusions}

Alfalfa mulch significantly improved tree vigor and fruit yield with minimal adverse effects on fruit quality, whereas the CDS amendment had minor effects on vigor and yield. Both alfalfa mulch and CDS amendment increased availability and uptake into leaves and fruit of most key nutrients but plant nutrient concentrations were not deficient in control plots, suggesting that increased nutrient availability was probably not the primary reason for the increased vigor attributed to alfalfa mulch at this site. Our data do indicate, however, that these materials could improve apple nutrient uptake on more nutrient-poor sites or in later years as the demands for $\mathrm{P}, \mathrm{K}$, and $\mathrm{Mg}$ uptake by larger trees increase. The alfalfa mulch resulted in elevated populations of microbivorous nematodes and protozoa that persisted through later years of the experiment, indicating greater overall microbial activity, mineralization of nutrients, and possible direct stimulation of root growth under mulch; the CDS did not consistently enhance populations of microbivorous nematodes. The alfalfa mulch, but not CDS, suppressed the buildup of populations of root-lesion nematodes, which are important components of the replant disease complex that was suppressing tree growth at the site despite the preplant fumigation. Accordingly, we speculate that the reduced impacts of root-lesion nematodes contributed to the improved vigor and fruit yield of trees grown with alfalfa hay mulch. In general, mulching with alfalfa hay was the most effective treatment at this site, providing establishment benefits and root-lesion nematode suppression.

\section{Literature Cited}

Akhtar, M. and A. Malik. 2000. Roles of organic soil amendments and soil organisms in the biological control of plant-parasitic nematodes: A review. Bioresour. Technol. 74:35-47.

Bongers, T. 1999. The Maturity Index, the evolution of nematode life-history traits, adaptive radiation and cp-scaling. Plant Soil 212:13-22.

Bonkowski, M., C. Villenave, and B. Griffiths. 2009. Rhizosphere fauna: The functional and structural diversity of intimate interactions of soil fauna with plant roots. Plant Soil 321:213-233.

Cline, J., G. Neilsen, E. Hogue, S. Kuchta, and D. Neilsen. 2011. Spray-on-mulch technology for intensively grown irrigated apple orchards: Influence on tree establishment, early yields, and soil physical properties. HortTechnology 21:398-411.
Faust. 1989. Physiology of temperate zone fruit trees. John Wiley and Sons, New York, NY.

Ferris, H., T. Bongers, and R.G.M. de Goede. 2001. A framework for soil food web diagnostics: Extension of the nematode faunal analysis concept. Appl. Soil Ecol. 18:13-29.

Ferris, H. and M.M. Matute. 2003. Structural and functional succession in the nematode fauna of a soil food web. Appl. Soil Ecol. 23:93-110.

Ferris, H., S. Sanchez-Moreno, and E.B. Brennan. 2012. Structure, functions and interguild relationships of the soil nematode assemblage in organic vegetable production. Appl. Soil Ecol. 61:16-25.

Forge, T.A., E. Hogue, G. Neilsen, and D. Neilsen. 2003. Effects of organic mulches on soil microfauna in the root zone of apple: Implications for nutrient fluxes and functional diversity of the soil food web. Appl. Soil Ecol. 22:39-54.

Forge, T.A., E.J. Hogue, G. Neilsen, and D. Neilsen. 2008. Organic mulches alter nematode communities, root growth and fluxes of phosphorus in the root zone of apple. Appl. Soil Ecol. 39:15-22.

Forge, T.A. and C. Kempler. 2009. Organic mulches influence population densities of root-lesion nematodes, soil health indicators, and root growth of red raspberry. Can. J. Plant Pathol. 31:241-249.

Forge, T.A. and J. Kimpinski. 2007. Nematodes, p. 415-425. In: Gregorich, E.G. and M.R Carter (eds.). Soil sampling and methods of analysis. 2nd Ed. CRC Press, Boca Raton, FL.

Forge, T.A. and S.W. Simard. 2001. Structure of nematode communities in forest soils of southern British Columbia: Relationships to nitrogen mineralization and effects of clearcut harvesting and fertilization. Biol. Fertil. Soils 34:170-178.

Granatstein, D. and E. Sanchez. 2009. Research knowledge and needs for orchard floor management in organic tree fruit systems. Intl. J. Fruit Sci. 9:257-281.

Hassink, J., L.A. Bouwman, K.B. Zwart, and L. Brussard. 1993. Relationships between habitable pore space, soil biota and mineralization rates in grassland soils. Soil Biol. Biochem. 25:47-55.

Hogue, E.J. and G.H. Neilsen. 1987. Orchard floor vegetation management. Hort. Rev. 9:377-430.

Ingham, R.E. 1994. Nematodes, p. 459-490. In: Weaver, R.W., chair, et al. (eds.). Methods of soil analysis part 2-Microbiological and biochemical properties. Soil Science Society of America, Inc., Madison, WI.

Litterick, A.M., L. Harrier, P. Wallace, C.A. Watson, and M. Wood. 2004. The role of uncomposted materials, composts, manures, and compost extracts in reducing pest and disease incidence and severity in sustainable temperate agricultural and horticultural crop production-A review. Crit. Rev. Plant Sci. 23:453-479.

Mazzola, M. and L.M. Manici. 2012. Apple replant disease: Role of microbial ecology in cause and control. Annu. Rev. Phytopathol. 50:45-65.

McSorley, R. 2011. Overview of organic amendments for management of plant-parasitic nematodes, with case studies from Florida. J. Nematol. 43:69-81.

Neilsen, G.H., E.J. Hogue, T. Forge, and D. Neilsen. 2003a. Mulches and biosolids affect vigor, yield and leaf nutrition of fertigated high density apple. HortScience 38:41-45.

Neilsen, G.H., E.J. Hogue, T. Forge, and D. Neilsen. 2003b. Surface application of mulches and biosolids affect orchard soil properties after 7 years. Can. J. Soil Sci. 83:131-137.

Neilsen, G.H., E.J. Hogue, T. Forge, D. Neilsen, and S. Kuchta. 2007. Nutritional implications of biosolids and paper mulch applications in high density apple orchards. Can. J. Plant Sci. 87:551-558.

Neilsen, G.H. and D. Neilsen. 2003. Nutritional requirements of apple, p. 267-302. In: Ferree, D.C. and I.J. Warrington (eds.). Apples: Botany, production and uses. CABI Publ., Oxford, UK.

Neilsen, G.H., D. Neilsen, P. Toivonen, and L. Herbert. 2008. Annual bloom-time phosphorus fertigation affects soil phosphorus, apple tree phosphorus nutrition, yield and fruit quality. HortScience 43:885-890.

Neilsen, G.H. and J. Yorston. 1991. Soil disinfection and mono-ammonium phosphate fertilization increase precocity of apples on replant problem soils. J. Amer. Soc. Hort. Sci. 116: 651-654.

Noble, R. and E. Coventry. 2005. Suppression of soil-borne plant diseases with composts: A review. Biocontrol Sci. Technol. 15:3-20.

Oka, Y. 2010. Mechanisms of nematode suppression by organic soil amendments-A review. Appl. Soil Ecol. 44:101-115.

Parchumchuk, P., R.C. Berard, and T.W. Van der Gulik. 1996. Automated irrigation scheduling using an electronic atmometer, p. 1099-1104. In: Camp, C.R., E.J. Sadler, and R.E. Yoder (eds.). Evapotranspiration and irrigation scheduling. Amer. Soc. Agr. Engn. Proc. Intl. Conf., San Antonio, TX.

Parfitt, R.L., G.W. Yeates, D.J. Ross, A.D. Mackay, and P.J. Budding. 2005. Relationships between soil biota, nitrogen and phosphorus availability, and pasture growth under organic and conventional management. Appl. Soil Ecol. 28:1-13.

Peryea, F., G.H. Neilsen, and D. Faubion. 2007. Start-timing for calcium chloride spray programs influences fruit calcium and bitter pit in 'Braeburn' and 'Honeycrisp' apples. J. Plant Nutr. 30:1213-1227.

Rønn, R., F. Ekelund, and S. Christensen. 1995 Optimizing soil extract and broth media for MPN enumeration of naked amoebae and heterotrophic flagellates in soil. Pedobiologia (Jena) 39:10-19.

Sanchez-Moreno, S. and H. Ferris. 2007. Suppressive service of the soil food web: Effects of environmental management. Agr. Ecosyst. Environ. 119:75-87.

SAS Institute Inc. 2000. SAS/STAT user's guide, version 8.1. SAS Institute, Inc., Cary, N.C.

Shear, C.B. and M. Faust. 1980. Nutritional ranges in deciduous tree fruits and nuts. Hort. Rev. 2:142-163.

Stirling, G.R., S.R. Dullahide, and A. Nikulin. 1995. Management of lesion nematode (Pratylenchus jordanensis) on replanted apple trees. Aust. J. Exp. Agr. 35:247-258.

Washington, H.G. 1984. Diversity, biotic and similarity indices: A review with special relevance to aquatic ecosystems. Water Resour. Res. 18:653-694.

Woomer, P.L. 1994. Most probable number counts, p. 59-78. In: Weaver, R.W., chair, et al. (eds.). Methods of soil analysis part 2-Microbiological and biochemical properties. Soil Science Society of America, Inc., Madison, WI. 